$\mathrm{UH}$

iti

Universität Hamburg
Faculty Economics

and Social Sciences

Chair for Economic Policy

STAN A. DU PLESSIS / WOLFGANG MAENNIG

THE, 20.1.0 WQRLD CUP HIGH-FREQU ENSN

DANA BGOAQMTCS:EFFECTS PEN.



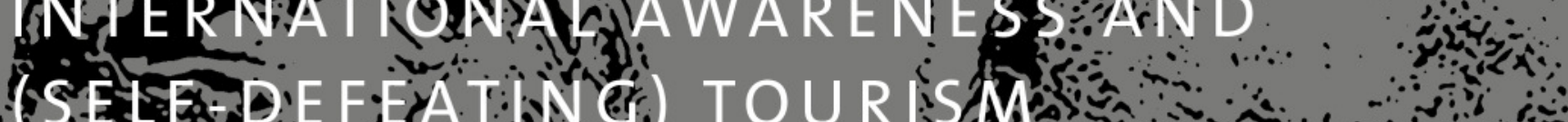

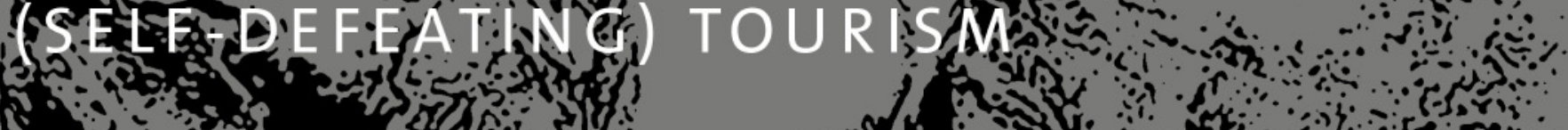

Si

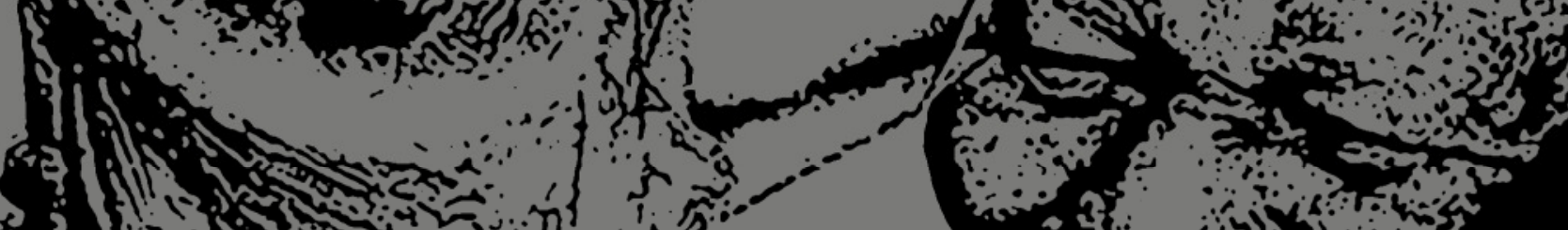



(1)

4. ? (1) HAMBURG CONTEMPORARV

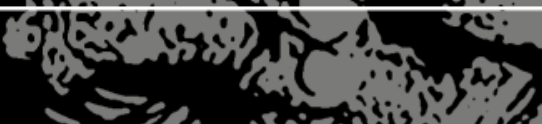

4 Transports

Sports:


Real Étáte





3: "ros?
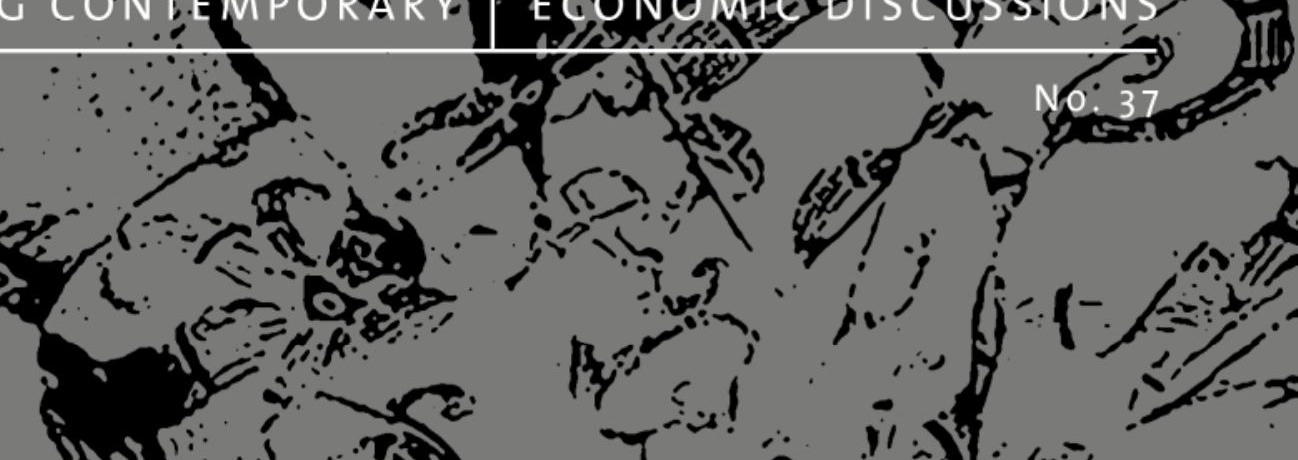
gisum 70

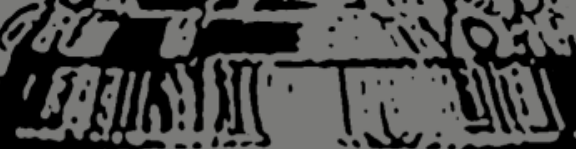


Hamburg Contemporary Economic Discussions

University of Hamburg

Faculty Economics and Social Science

Chair for Economic Policy

Von-Melle-Park 5

D-20146 Hamburg | Germany

Tel $+494042838-4622$

$\mathrm{Fax}+494042838-6251$

http://www.uni-hamburg.de/economicpolicy/

Editor: Wolfgang Maennig

Stan du Plessis

University of Stellenbosch and

Bureau for Economic Research

Department of Economics

stan@sun.ac.za

Wolfgang Maennig

University of Hamburg

Faculty Economics and Social Science

Chair for Economic Policy

Von-Melle-Park 5

D-20146 Hamburg | Germany

Tel $+494042838-4622$

Fax $+494042838-6251$

maennig@econ.uni-hamburg.de

ISSN 1865 - 2441 (Print)

ISSN 1865 - 7133 (Online)

ISBN $978-3-940369-88$ - 8 (Print)

ISBN $978-3-940369-89-5$ (Online) 


\title{
The 2010 World Cup High-frequency Data Economics:Effects on International Awareness and (Self-defeating) Tourism
}

\begin{abstract}
Without a doubt, the 2010 World Cup of soccer in South Africa was a great experience for both soccer fans, who enjoyed a safe and efficiently-run tournament, and their South African hosts. The sporting and social spectacle was broadcast around the world and focused unprecedented media attention on South Africa. Despite the manifest success of the tournament, its short-term effects on international tourism, which are the nucleus of all other short-term positive effects on economic variables such as employment, income and taxes, have turned out to be of a much smaller magnitude than expected or even as reported during the tournament. This may be attributable to self-defeating prophecy effects. This study is a warning against the abuse of economic impact studies, especially those pertaining to major sporting events. It is also a call to use the "correct" arguments of measurable awareness effects and potential long-term development effects in discussing major sporting events. Methodologically, this study is innovative in its economic analysis of major sporting events because it (i) uses data from social networks and (ii) uses high-frequency daily data on tourism.

Key words: FIFA World Cup, Mega Sporting Events, Sport Economics, Tourism, South Africa 2010, Selfdefeating prophecies, Awareness, Google, Facebook, Social Networks

JEL classification: L83 R53, R58
\end{abstract}

Version: August 2010

\section{Introduction}

The 2010 World Cup was clearly successful as a sporting event and as an advertisement for South Africa's capacity to host a global event. Expectations were high prior to the tournament regarding the home team's performance and the tournament's magnitude as a major event and potential benefit for the South African economy.

The home team's strong performance relative to reasonable expectations was the source of much local pride. Further, the tournament was an organisational and 
logistical success (ZORN 2010) despite the sometimes-pessimistic forecasts in the international media. ${ }^{1}$ The "summa cum laude" grade assigned to the World Cup by FIFA-president Sepp Blatter (REVEES 2010) was not contradicted by an otherwise critical press.

An economic analysis of the 2010 World Cup should be conducted at the micro or managerial level of the Local Organising Committee (LOC) and of FIFA. There is currently little information about the financial outcomes of the LOC. FIFA, which earned 3.4 billion USD in total commercial revenues (N.N. 2010a) provided the LOC with 423 million USD, an amount that is considered to have been sufficient to ensure that the tournament was within budget (PEDRONCELLI 2010). The costs of the stadiums and the transportation infrastructure were almost entirely publicly financed, but those costs should not be attributed solely to the World Cup, due to the long-term benefits of such investments. It is too early to assess the ultimate impact of these public investments on the long-run growth path of the economy.

On a micro-level, there are always winners, losers and those who are unaffected by such a major event. For example, there are reports of increased demand for vuvuzelas, travel in luxury coaches, for tour operators, and for tourist attractions in close proximity to stadiums. ${ }^{2}$ Meanwhile South African manufacturers seem to have been largely unaffected by the event. ${ }^{3}$ In terms of the events' negative impact, the lives of many South Africans were disrupted by the preparation for the tournament and by the tournament itself.

To appreciate the total economic impact of a major sporting event, it is necessary to move beyond data on individual enterprises and sectors to investigate the ef-

1 A few critics did point to the low attendance at some of the matches. FIFA president Blatter argues that this was not due to an inappropriate pricing policy (for details see MAENNIG and DU PLESSIS 2007), but instead that it was due to a poor uptake of hospitality tickets. Overall, $95 \%$ of the tickets to the matches were sold (N.N., 2010b).

2 Email by MARIETTE DU TOIT-HELMBOLD (Cape Town Tourism) on 25 June 2010.

3 Statement of COFACE, SA's trade credit protection company, email by Denny Thaver (thaverdenny@durban.gov.za) of July 2nd, 2010. 
fect of the tournament using meso- and macro-economic data. These data have the advantage of aggregating possible increases in the incomes of individuals with the losses of others, thereby presenting a general economic picture.

\section{International tourism: The origin of short-term income and employment effects}

During the event, the increase in income and employment generated by a major sporting event can only result from additional expenditures by non-residents visiting the event region. Expenditures by domestic residents do not contribute to the impact of the event; even if individuals purchase televisions and other items used in relation to the event, the event usually affects the timing of the consumption decisions rather than the overall level of consumption and savings. Increased consumption by residents during the tournament is typically counterbalanced by reduced demand in other months and/or in other sectors, leaving the savings rate unaffected at least in the medium term.

This explains the emphasis on international tourism in ex ante impact studies of the effect of the 2010 World Cup, one of the largest major sporting events. The event raised high expectations: 230,000 foreign tourists were predicted to stay for an average of 15 days (GRANT THORNTON 2004), and this number even increased to 380,000 overseas visitors (GRANT THORNTON 2008). A distinction between "overseas tourists" and "international tourists" is important in the South African case due to an expected difference in the spending patterns between tourists from within the region and those from Europe, Asia, and the Americas.

Such forecasts were well-received on the basis of the perceived effects of previous large sporting events hosted in South Africa in the low-tourist-season months in South Africa including the rugby and cricket world cups (SPRONK \& FOURIE, 2010). Early warnings from experienced World Cup host nations like France (1998) and Germany $(2006)^{4}$ as well as European Cup organisers that the net in-

${ }^{4}$ Cf. MAENNIG \& DU PLESSIS (2007), ALLMERS \& MAENNIG (2010). 
crease of the number of tourists that accompanies the World Cup is typically small or even insignificant garnered little attention in South Africa. The optimistic expectations were reflected in the considerable private sector investment in the tourism sector in the years leading up to the tournament. Table 1 compares the number of hotel beds available in the various categories of hotels in 2007 and 2010.

Tab. 1 The Supply of Hotel Beds in South Africa

\begin{tabular}{lccc}
\hline \hline Level & 2007 & 2010 & Avg growth p.a. \\
\hline 5 star & 8013 & 10295 & 8.7 \\
4 star & 12585 & 21049 & 18.7 \\
3 star & 23714 & 26698 & 4 \\
2 star & 3559 & 4185 & 5.5 \\
1 star & 3156 & 3645 & 4.9 \\
Total & 51027 & 65872 & 8.9 \\
\hline
\end{tabular}

Source: Pam Golding Tourism \& Hospitality Consulting (PAM GOLDING, 2010).

While there was considerable expansion in the admittedly low hotel capacity over this period, especially at the luxury end of the market, it would not be appropriate to attribute this solely or even largely to the approaching World Cup. Instead, rising demand had long necessitated investment in extra capacity. Nevertheless, the approaching World Cup affected the timing of these projects, advancing their completion dates in anticipation of the tournament. Some of this investment is of doubtful long-term viability, and there is a risk that some of the new hotels will fail when room occupancy and rates per room drop after the tournament (Cokayne, 2010).

The available hotel beds listed in Table 1 exclude the many guesthouses in the South African tourism sector. Regrettably, there is no formal estimate of the number of these establishments and their available beds. However, the Department of Tourism reported that prior to the tournament, approximately one-third 
of the accommodations pre-booked through FIFA's MATCH system were nonhotel accommodations (Department of Tourism, 2010).

Official data on tourist arrivals during the tournament are not yet available. Statistics South Africa publishes a monthly review of tourism (and migration) but with a three-month delay. A number of estimates of tourist arrivals are available, but these are highly divergent (Blitz and Lapper, 2010). High forecasts are on the order of 350,000, such as the Grant Thornton prediction of 373,000 made shortly before the tournament (Baumann, 2010; N.N. 2010c). Some estimates even exceed 500,000, such as the estimate reportedly made by the LOC mid-way through the tournament (Naidu and Piliso, 2010). Estimates at the lower end are close to 200,000 (Du Plessis and Venter, 2010). On a regional level, a survey conducted by Cape Town Tourism indicated that occupancy levels in the Cape Town Metropole for the first two weeks of the tournament averaged $34 \%$ in the first week and $40 \%$ in the second week of the World Cup, with positive effects for accommodations in the neighbourhood of Green Point stadium. However, establishments that were further afield were disappointed in the number of reservations. ${ }^{5}$

This paper contrasts such numbers with evidence from two sources. We first use data on actual arrivals at the international airports. Second, we use data on occupancy rates in the hotels of the major cities. To begin the analysis, we note that the number of international airplane landings did not increase substantially between June 2009 and June 2010. Daily data on airplane landings at the three South African international airports in Johannesburg, Cape Town, and Durban were collected from http://www.acsa.co.za/index.asp. Figure 1 plots the number of international flights arriving at the three South African international airports between 12 April, 2010 and 2 August ' $2010 .^{6}$

The average number of international arrivals per day for all three airports on the dates of 10 June (the day before the opening ceremony of the World Cup and the

Email Mariette Du Toit-Helmbold [marietted@capetown.travel] from: 25 June 2010.

${ }^{6}$ It is clear from figure 1 that the vast majority (around $88 \%$ ) of international flights arrive at Johannesburg. 
first day with a visible increase in arrivals) and 11 July (the day of World Cup final) increased to an average of 133 from an average of 126 international arrivals in the time period from 12 April until 9 June: an average addition of seven airplane arrivals per day. The aircraft typically used for international flights and their seat capacities are the following: ${ }^{7}$ the Airbus A321 with a maximum of 220 passengers, the Boeing 747-400 with 416 seats and all pax models of the Boeing 767, with a range of 181 to 245 seats. Air France and Lufthansa are reported to have used the new Airbus A380, at least occasionally, which has a substantially higher seat capacity.

We assume that the World Cup did not affect the seat capacity of the international airplanes used on the relevant routes. We also assume that the capacity utilisation of the additional flights was always close to $100 \%$ as is typical on this route and other overseas flights. We are aware that this creates a bias towards higher numbers of tourists because some of the landings presumably did not bring many tourists but were intended to fly tourists (or less successful soccer teams) out of the country. With approximately 7 additional per day arrivals over a period of 33 days (from June $9^{\text {th }}$ until July $11^{\text {th }}$ ) the largest possible increase in tourist arrivals could have been close to 90,000 .

\footnotetext{
${ }^{7}$ http://www.cheapfares.de/fluege/flugsuche.html?fid=38\&sid=2010071217093237ysdcwomvaj cgcn\&agent=welt1aama\&AorK=K\&from=FRA\&Day=16\&month_1=072010\&to=JNB\&RetDay $=24 \&$ month_2 $=07-$ 2010\&pax $=1 \&$ pax_chd=0\&pax_inf $=0 \&$ tarif_klasse $=\& o n e w a y s w i t c h=0 \& e i d=a m a s$
} 
Fig. 1 Number of Flights from International Destinations at South African International Airports, April 12 $2^{\text {th }}$-August $2^{\text {nd }}, 2010$.



Source: http://www.acsa.co.za/index.asp, daily observations

This modest estimate does not contradict claims such as those by Cape Town Tourism $^{8}$ indicating that the number of international arrivals in Cape Town was 44\% higher in June 2010 than in June 2009. First, the base period is modest: the number of international tourists visiting South Africa in 2009 was sharply down from previous years. Total quarterly arrivals from the USA, Great Britain and Germany, which make up approximately $45 \%$ of total air arrivals, reached more than 250,000 visitors during the high season from 2004 until the summers of 2007 and 2008 before dropping (during the first two quarters of 2009) to levels not seen since 2003. Second, the number of international arrivals in Cape Town estimated by those in Cape Town Tourism seems to include those tourists who initially landed in Johannesburg.

We now turn to the second approach to estimating additional tourism from the World Cup, that using hotel occupancy rates. Table 2 shows the hotel occupancy rates for the three major centres of Cape Town, Durban and Gauteng for each

8 Email form Mariette Du Toit-Helmbold, June 25th, 2010. 
month of June since 2007. Figure 2 shows the same data, but in terms of the daily frequency for June 2010.

Tab. 2 Hotel Occupancy Rates in the Major Cities

\begin{tabular}{cccc}
\hline & Cape Town & Durban & Gauteng \\
\hline Jun 2006 & 52.5 & 79.6 & 68.2 \\
Jun 2007 & 55 & 74.2 & 73.1 \\
Jun 2008 & 48.1 & 74.6 & 72.5 \\
Jun 2009 & 49.7 & 67.3 & 65.5 \\
Jun 2010 & 52.1 & 59.6 & 76.8 \\
\hline
\end{tabular}

Source: STR Global

Fig. 2 Hotel Occupancy Rates in the Major Cities for June 2010 (in \%)

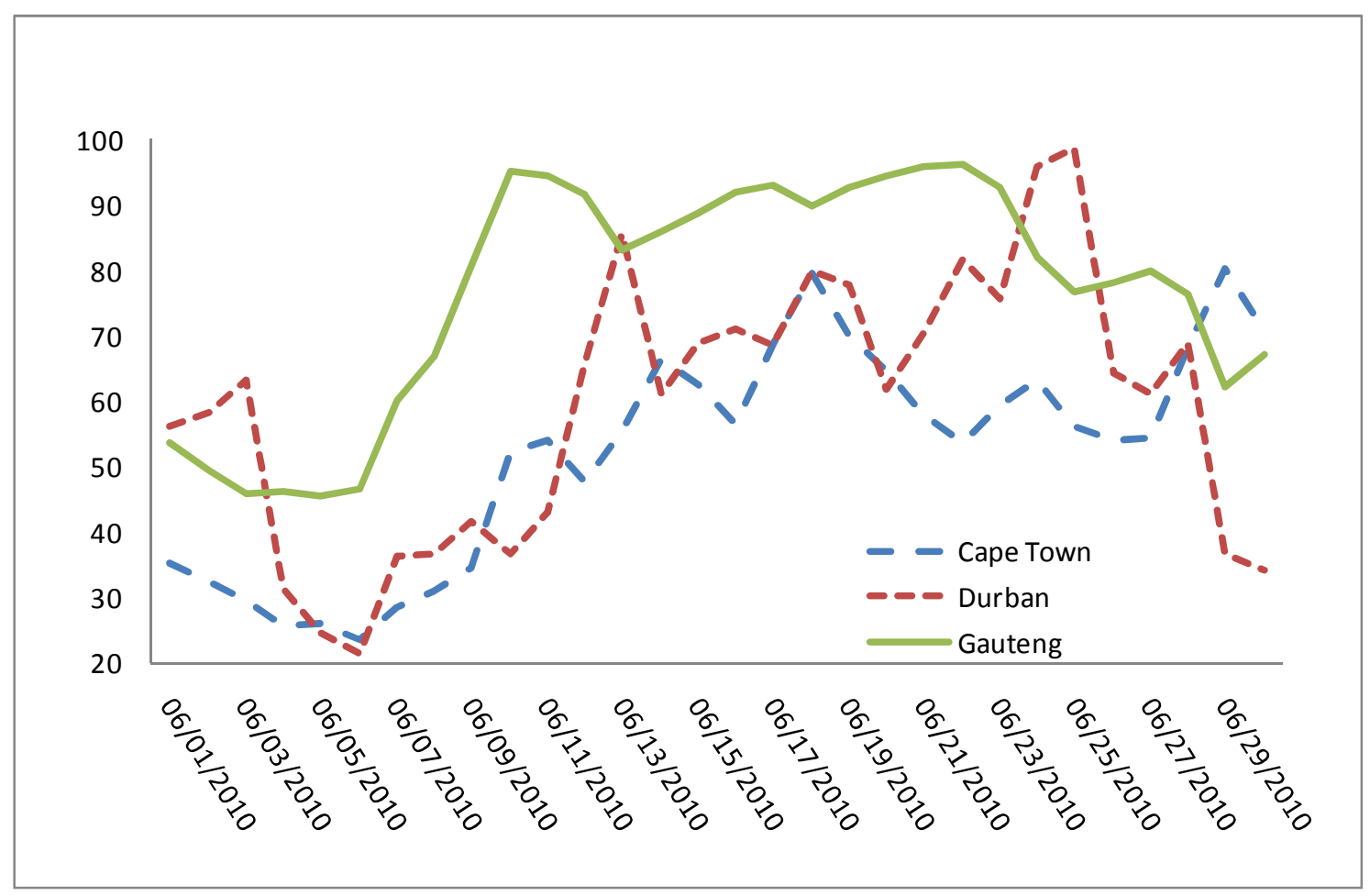

Source: STR Global

The data in Figure 2 should be read alongside the information on capacity expansion in Table 1, which indicated that growth especially occurred within high-end accommodation. Figure 2 shows the extent to which World Cup visitors used Gauteng as their base for the tournament due to the number of stadiums in close 
proximity and the easy access by road and air to more distant stadiums. In terms of occupancy, Cape Town experienced a better-than-average June, though not by much, and in Durban, occupancy continued its long decline.

Combining the occupancy rates for 2009 with the number of available hotel rooms ${ }^{9}$ in the major cities gives a figure of 3,045 additional hotel rooms occupied on an average day in June 2010 (and an additional 1,500 occupied guest houses). Making the further assumptions that these guests stayed an average of 5 days and that $80 \%$ of the rooms were occupied by 2 persons with the remainder in single occupancy yields approximately 40,000 more tourists staying in hotels and guest houses during June 2010 compared with June 2009.

A number of factors are likely to have played a role in the disappointingly small tourism impact of the World Cup. The first is the international recession, which is likely to have lowered international demand for tickets to South Africa. Our data on arrivals compare the World Cup period to the days before and after the events, which were affected by the crisis in the same manner, but without the crisis, the numbers of tourists both before and during the event could have been substantially larger.

More generally, potential reasons for the impact of major sporting events on tourism are well described in the scholarly literature: ${ }^{10}$ One important effect is the crowding-out of "normal" tourists due to the noise, traffic jams and other disturbances that are expected to be caused by the World Cup and the preparation for the event. In the South African case, there was considerable crowding-out of tourism in the hunting sector, a market where June is typically the peak of the hunting season (SAPA-AP, 2010).

9 The data in Table 1 was aggregated at the national level, while the occupancy rates were for Gauteng, Cape Town and Durban. During June 2010 there were 23,518 beds hotel beds available in Gauteng, 16,245 in Cape Town and 10,546 in Durban.

${ }^{10}$ Cf. COATES \& HUMPHREYS (2000), BAADE \& MATHESON (2004), DU PLESSIS \& MAENNIG (2008), ALLMERS \& MAENNIG 2009. 
As a special form of crowding-out, price-crowding-out is sometimes mentioned in the scholarly literature but rarely supported with data. In the case of South Africa, a special form of price-crowding-out may have been at work: self-defeating prophecies via an ex-ante supply-price-crowding-out channel. This form of pricecrowding-out must be distinguished from some press reports that hinted at the high cost for Europeans and Americans to attend the World Cup, which is usually interpreted through the phrase: "the problem is that it is a long-haul destination" (N.N. 2010d).

The long flight does not seem to have been the main constraint, however. Rather, the pricing policy in the tourist industry seems to have played an important role. Figures $3 a$ and $3 b$ depict the seven-day moving averages ${ }^{11}$ of prices for flights from Frankfurt, London, Madrid, Paris, and Rome to Johannesburg on fixed days during, before and after the World Cup.

The (cheapest) prices of such flights were collected on a daily basis beginning on 15 December 2009 via the publically available internet portal www.bookandsmile.com. The airports included are the international hubs of the nations that were expected to have the most influential soccer teams in the tournament, and a large portion of the expected tourism was to be expected from these nations. In the case of the flight connection between Frankfurt and Johannesburg on 9 May, 2010 (a date well before the World Cup) the supply price between 15 December 2009 and 8 May 2010 varied by approximately 350 EUR for most of the observation period and by approximately 480 EUR in the period from the middle of March 2010 to the beginning of April 2010, with an average variation of 387.2 EUR. For the same flight on 9 June 2010, prices were over 900 EUR during the period between end of January and the end of March. From that time forwards, there was a downward correction in flight prices, possibly due to a combination of an intervention by South Africa's Competition Commission and the realisation by the airlines that they would not be able to reach sufficient

${ }^{11}$ A moving average was used in order to adjust for a (mostly weekend based) systematic fluctuation in daily prices. 
bookings for their flights at those fares. However, even after this correction, prices for flights were consistently at least $50 \%$ higher than in the non-World Cup periods. ${ }^{12}$

Flight prices for the other connections between the major European airports and Johannesburg had similar developments to the one describe for Frankfurt. We restrict ourselves to providing an additional figure $3 b$ for London. ${ }^{13}$ The pricecrowding-out effect indicated by these figures might have been biased downwards because our statistics exclusively use the cheapest flights, and do not control for the number of flight seats available for this price.

Fig. 3a Prices for Frankfurt-Johannesburg Flight Connections for Flight Dates 9 May/ 9 June/ July, $9^{\text {th }}$ and 9 August. Seven-day moving Average of the Cheapest Prices between 15 December, 2009 and 3 August, 2010.

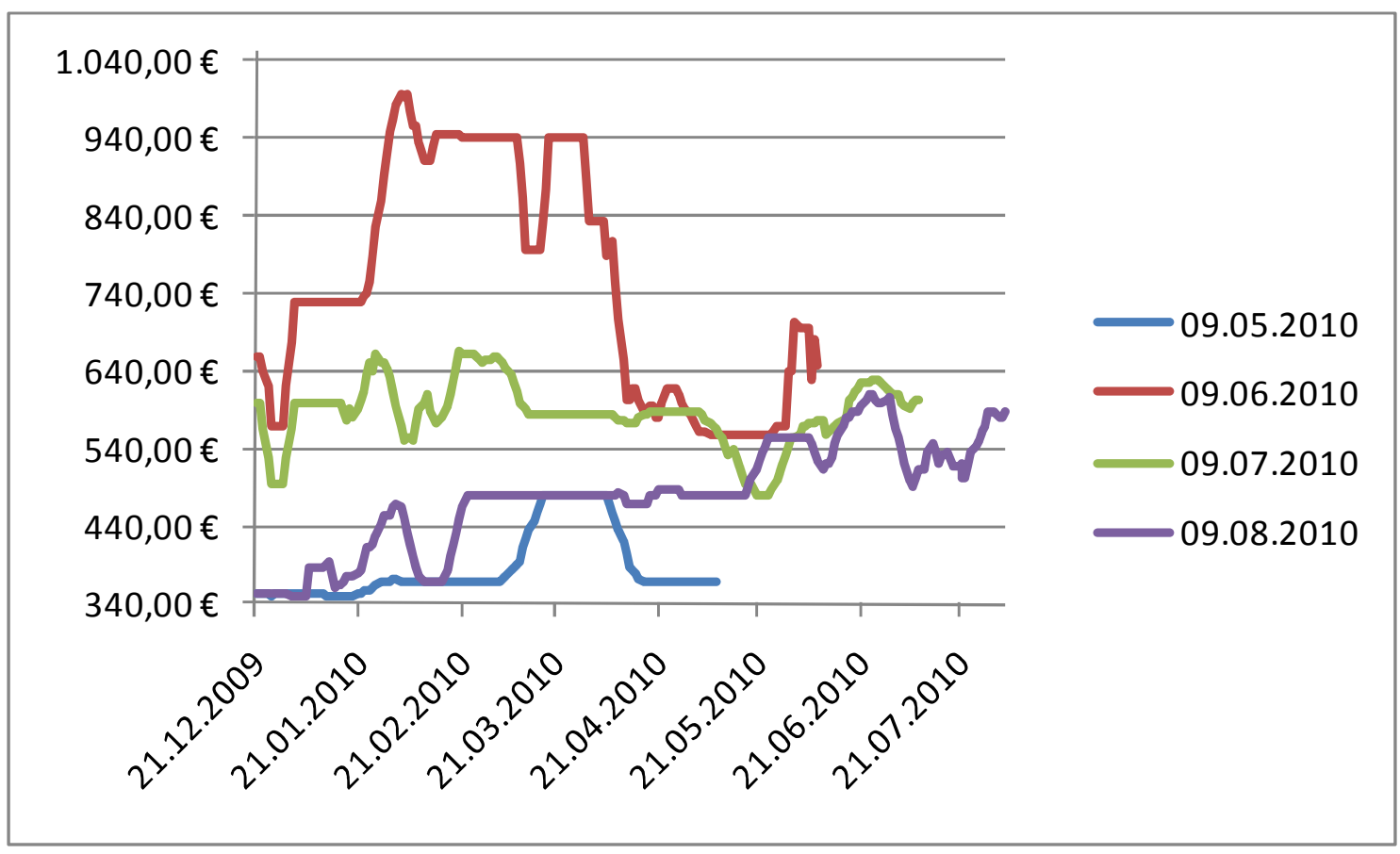

12 The peculiar price development on August 9 might be explained by the South African public holiday on that day. This may have caused there to be fewer flights by SAA on that day, which raises the prices elsewhere.

${ }^{13}$ The figures for the other European flight connections are available on request from the authors. 
Fig. 3b Prices for London-Johannesburg Flight Connections for Flight Dates 9 May, 9 June, 9 July and 9 August. Seven-day Moving Average of the Cheapest Prices between 15 December, 2009 and 3 August, 2010.

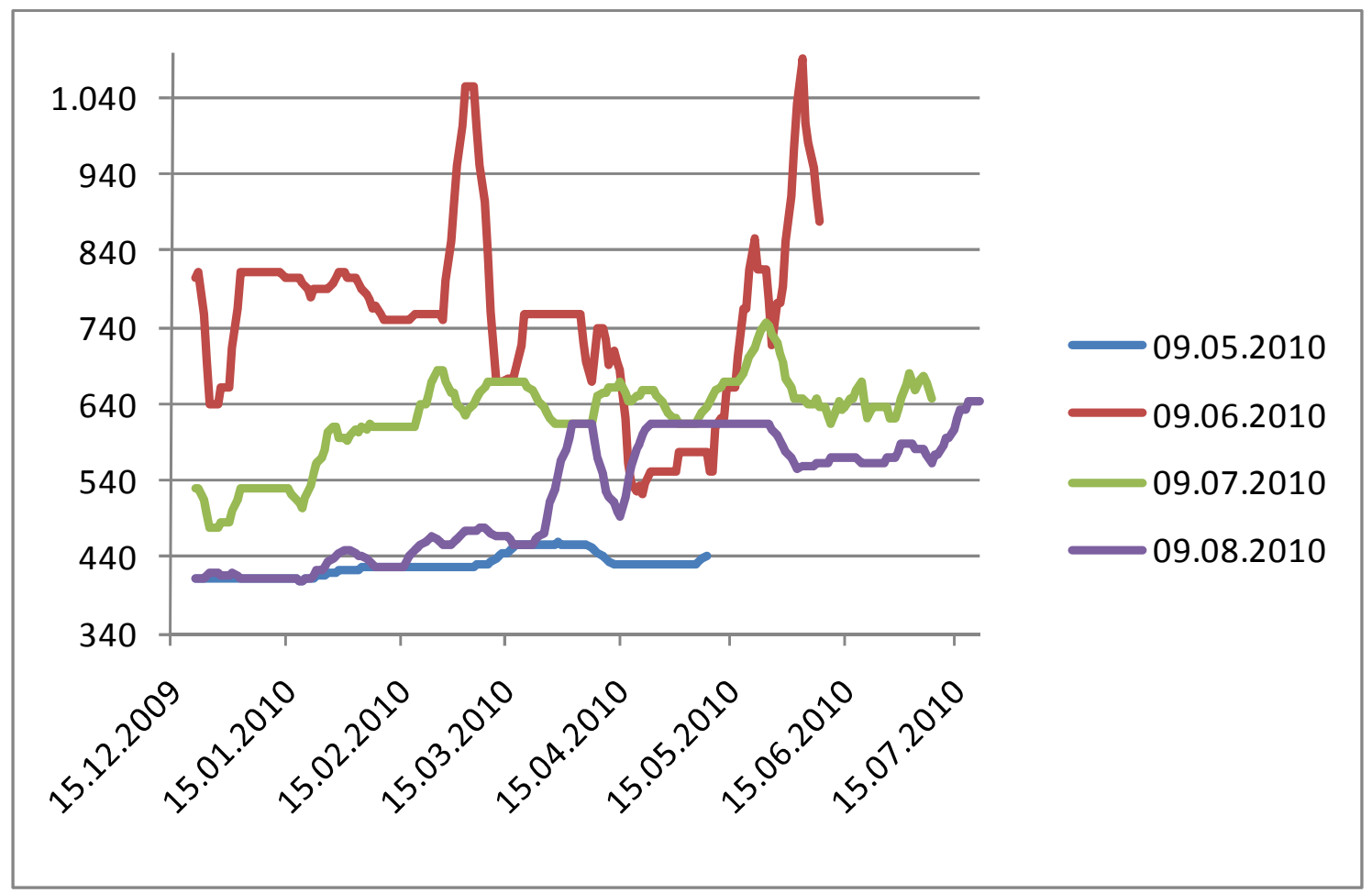

An additional factor that could have constrained demand was the relatively high local tourist sector prices (in dollar terms). To illustrate this factor, Figure 4 shows the Econex/Portfolio real price index ${ }^{14}$ in Rand and Dollar terms. The influence of Rand appreciation on this index is clear, leading to higher dollar prices for international tourists over the last 5 years.

14 The Econex/Portfolio price index reflects the price of accommodation in the tourist sector in South Africa. 
Fig. 4 Rand and Dollar Tourist Sector Price Index

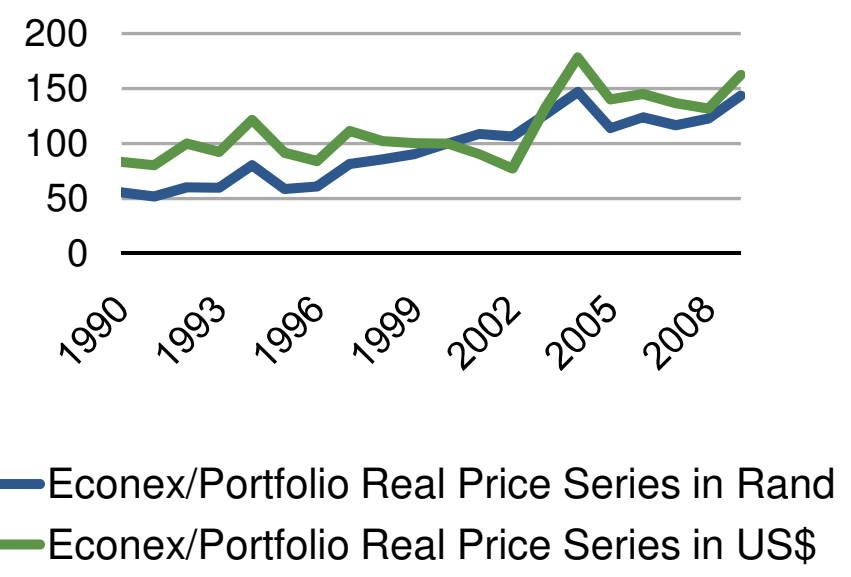

Source: Econex

Further, higher-than-normal hotel prices may have affected the number of tourists visiting the World Cup. As with the 2006 World Cup, there is clear evidence that the inflexibility of the tournament schedule improved the pricing power (in local currency) of hotels more than is usual for the season, and that improvement is reflected in the average room rates (in Rand, adjusted for inflation) reported in Table 3. Figure A1 shows the room rates on a daily basis for June 2010 . The table shows the actual average Rand amount charged in these cities per room.

Tab. 3 Average Room Rates per Day - in Rand Constant 2006 Prices

\begin{tabular}{lccc}
\hline & Cape Town & Durban & Gauteng \\
\hline Jun 2006 & 649.3 & 549.2 & 544.1 \\
Jun 2007 & 683.3 & 590.4 & 632.5 \\
Jun 2008 & 687.1 & 625.8 & 691.3 \\
Jun 2009 & 725.4 & 664.0 & 765.7 \\
Jun 2010 & 1983.1 & 1429.2 & 2181.8 \\
\hline
\end{tabular}

Source: STR Global 
Though the hotel prices reported above were the real prices, the decision to visit South Africa was made weeks and months ahead of time based on prices quoted at that time. We recorded the lowest quoted prices for hotel rooms collected on a daily basis since 30 April 2010 via the publically available internet portal www.hrs.de. ${ }^{15}$ Figure 5 reports that the lowest prices for accommodation in Johannesburg for 9 May and 9 August (both dates are near to but outside of the World Cup period) are more or less constantly between 45 EUR and 50 EUR per night over the entire data period. By contrast, during the World Cup period, it was not possible to book accommodation for less than 120 EUR per night at any point after late April. Advertisements for the cheapest accommodation increased to approximately 700 EUR for the night of 25 June if booked one month in advance. Accommodation suppliers obviously realised that they would not find sufficient bookings at such a high price and reduced supply prices, but subsequently it was still not possible to book accommodation for 25 June for less than approximately 260 EUR. Similar observations are available for the other World Cup cities. The same applies for the price quotations of car rentals. ${ }^{16}$

Air carriers, car rentals and hoteliers enjoyed an enhanced price environment during the World Cup, with rates doubling and tripling. Though comparable data does not exist for restaurants, this industry might also have benefited substantially during the tournament.

The negligible increase of the capacities of air carriers in combination with the sharp price increases depicts an inelastic supply and high windfall profits for the sector. It remains unclear as to whether the modest supply reaction by airlines was due to (i) internal information that on the basis of their pricing strategies, no additional supply would be needed or (ii) that the inherent logistical costs of changing the flight schedules would have been too high to increase supply. ${ }^{17}$

\footnotetext{
15 We also collected data from www.hotels.com, which did not result in different conclusions.

${ }^{16}$ Details are available form the authors on request.

17 Telecommunication with Mrs. Weber, personal assistant to Mr. Hunold, CEO of Air Berlin, 29 July 2010.
} 
Fig. 5 Prices for Hotel Accommodation in Johannesburg for the Dates 9 May , 12 June, 25 June , 11 July and 9 August. Seven-day Moving Average of the Cheapest Prices between 30 April, 2010 and 3 August, 2010.



The economy of a host nation may well experience increased income from such price effects, that is, higher prices may be accompanied by higher salaries. In the case of South Africa with its likely very elastic labour supply and its near-zero events-capacity effects, it seems more likely that the price increases translated to higher profits for capital owners. In the case of airfares, most of the profit clearly (with the exception of flights by South African Airways) went abroad. In the case of the hotel industry, no data on the capital shares of foreign investors are available, but at least in the case of the international hotel chains, a high proportion of the profit will not stay in South Africa (MATHESON 2009).

In sum, according to our data on additional international airplane landings, we do not see any evidence for a net increase in World-Cup-related overseas tourism beyond some 40.000 to approximately 90,000 persons. Even in World Cup cities, occupancy rates were far from $100 \%$ during the World Cup, implying that the South African economy could not make full use of its resources. 
Additionally, even this modest positive effect in June and July does not prove that the tournament had a positive tourism effect because "time-switcher" effects have to be considered. In the cases of the 2004 European Cup in Portugal and the 2006 World Cup in Germany, increased numbers of international tourist in the event months of June and July were partly or fully offset by lower numbers in other months. It is conceivable that tourists who would otherwise have travelled to the host nations during May or August transferred their stay in a utilitymaximising way to the World Cup months (ALLMERS \& MAENNIG 2009).

At this stage, we think it is fair to say that early and overly optimistic forecasts of approximately 400,000 overseas visitors contributed to the smaller-thanexpected tourism effect. These studies contributed to self-defeating prophecies: they induced pricing behaviour in important segments of the tourism industry that damped the potential increase in the number of tourists.

\section{Other Short-term Economic Effects and Potential Long- term Effects}

A feel-good effect might be the most evident positive outcome of Mega sporting events. Nevertheless, only a few studies attempt to evaluate this phenomenon of benefiting from (sports) events without active attendance at the stadium, and they do so through the concept of willingness to pay. Before the 2006 World Cup, only one out of five Germans surveyed revealed a 'willingness to pay' (WTP) greater than zero for the World Cup to take place in Germany (HEYNE et al., 2010). On average, the WTP was 4.26 EUR per person, which with 82 million inhabitants, corresponds to approximately 351.5 million EUR. After the World Cup, the proportion with a positive WTP had increased to $42.6 \%$ and the average was 10.0 EUR, amounting to 830.8 million EUR for the whole country. It follows that this feel-good effect was one of the largest effects of the World Cup. ${ }^{18}$ Although

18 JOHNSON \& WHITEHEAD (2000) study the willingness of people to pay for two stadium projects in Lexington, Kentucky even if they do not visit the stadiums. ATKINSON et al. (2006) evaluate the British WTP for the 2012 Olympic Games in London. 
no such measurements are yet available for South Africa in 2010, the feel-good effect was evident in the widely-reported enjoyment of the event by South Africans. $^{19}$

While the feel-good effect refers to the impact on locals, there is a related potential impact on foreigners due to an improved international perception of the host country. ${ }^{20}$ There is at least preliminary evidence for such awareness effects in South Africa from the 2010 tournament. Figure 6 uses the number of Google hits as a proxy for awareness and plots the index of the number of Google hits for the search words "South Africa", "Germany", "Namibia”, and "World Cup 2010" for each day from 19 April 2010 to 3 August 2010. The data is a visual representation of the rising awareness of South Africa and shows an increase of approximately $60 \%$ during the World Cup period compared with April 2010. The same metric of awareness for Germany, possibly due its national team performance, increased by up to approximately $40 \%$, whereas for Namibia it did not increase by more than $20 \%$ for any day in the observation period. The biggest increase in awareness was for the 2010 World Cup tournament itself, which might suggest that only part of major events awareness is directed towards the host country.

${ }^{19}$ See, for example, the account of the local experience in "World Cup: South Africa wins hearts after successful mundial" available at www.afriquejet.com/news/africa-news/world-cup:south-africa-wins-hearts-after-successful-mundial-2010071352645.html

${ }^{20}$ For the case of Germany 2006, see MAENNIG \& DU PLESSIS 2007. 
Fig. 6 Index of the Number of Google Hits from 19 April 2010 until 3 August 2010.

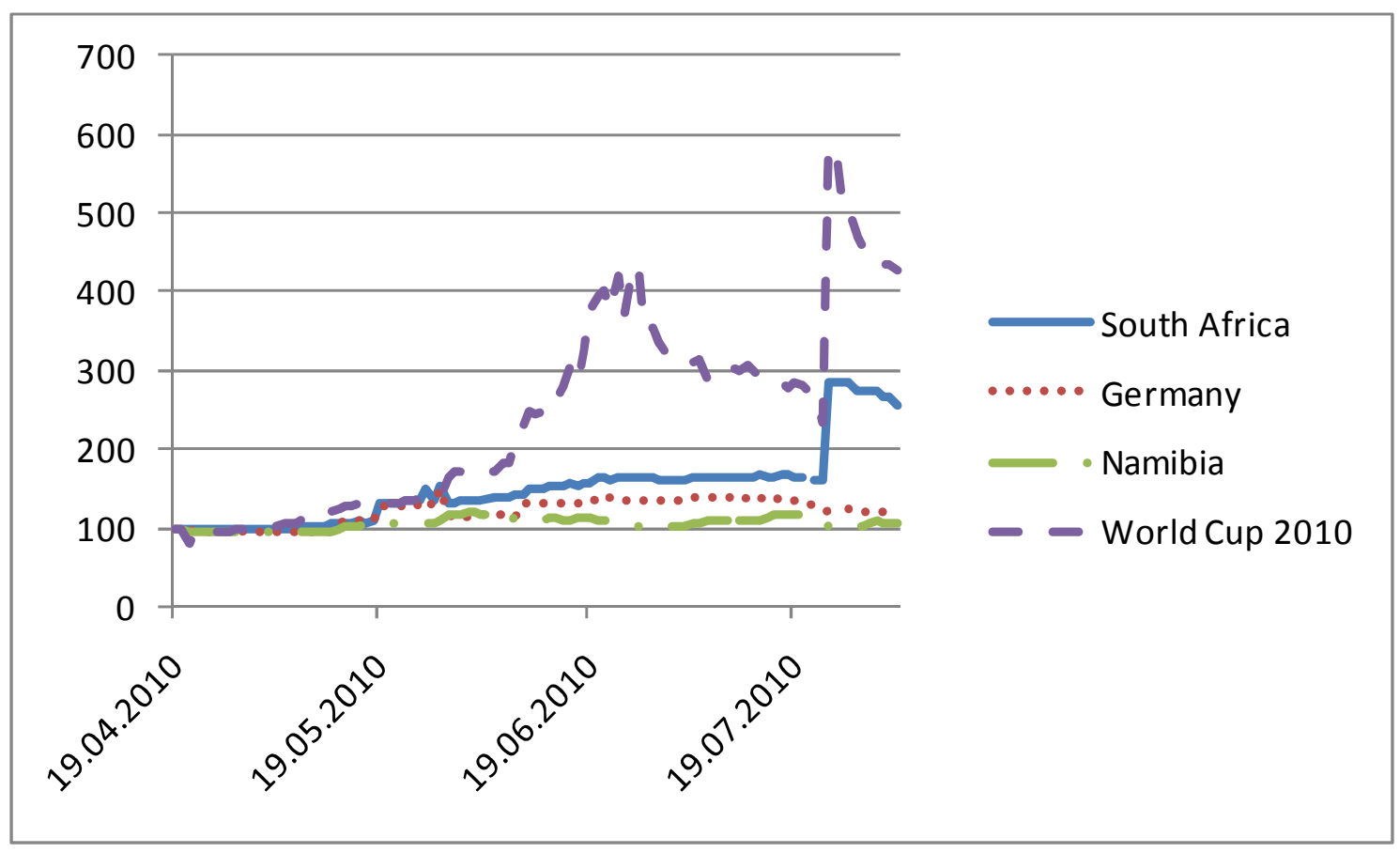

Google hits are a supply-side indicator, however, because Google records the number of webpages relevant to a given keyword. From a media economics perspective, the demand side is also interesting. As a proxy, we counted the number of members of the Facebook groups "South Africa 2010", "My South Africa", "Namibia", and "Super Bowl". Figure 7 plots the index of the number of these Facebook groups for each day from 19 April 2010 to 3 August 2010 and indicates that the number of members of "My South Africa" increased by approximately $20 \%$, well above the near-to-zero increase of the Facebook group "Super Bowl". It must be mentioned, however, that the number of members of the group "Namibia" increased at nearly the same extent. In addition, the number of members in the group "South Africa 2010" increased by more than $170 \%$, again relativising the awareness effect for the host country. 
Fig. 7 Index of the Number of Members in Facebook Groups from April $19^{\text {th }}$, 2010 until August $3^{\text {rd }}, 2010$.

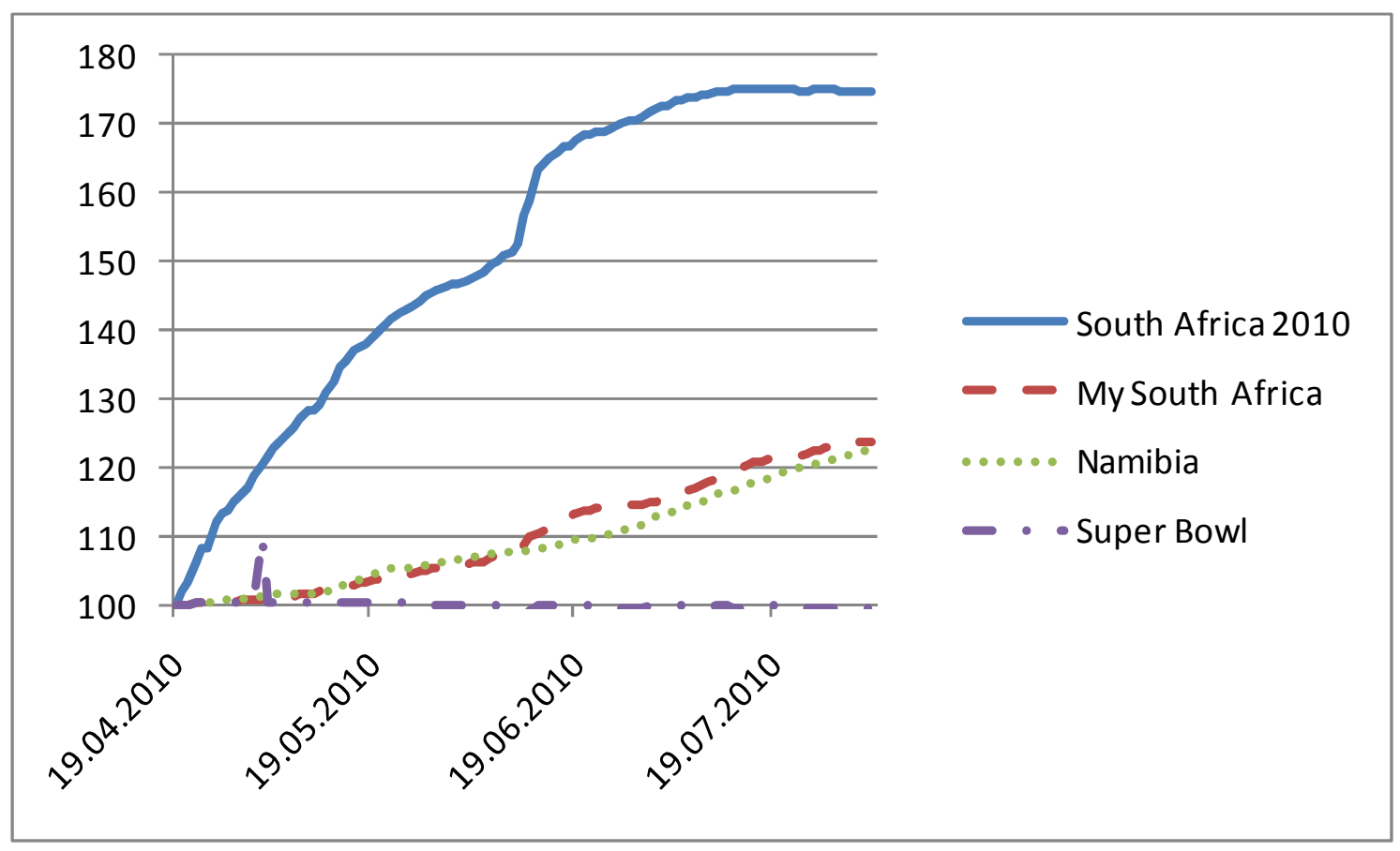

Besides awareness, another positive effect on the host country's sporting environment may apply in the long run: the positive effect of the new stadiums on spectator demand. In Germany, the "novelty effect" of all stadium projects since 1963 was equivalent in a rise in spectator numbers of approximately $10 \%$ per match (FEDDERSEN et al., 2006). In addition, the average revenue per ticket increases due to the expansion of the area for VIP and business seating, so the overall ticket proceeds may also increase. These increased receipts improve the ability of a club to acquire top players in the international market, which, in the medium term, leads to increased national and international competitiveness. Hence, from the point of view of sport, the new stadiums are a potential asset for South Africa.

New 'iconic' stadiums like those in Cape Town, Durban, Port Elizabeth and Johannesburg may also play a role in long-term urban development. There is no standard definition of 'iconic buildings', but there are plenty of examples among existing structures: the Sydney Opera House is inseparable from the worldwide image of that city, and the Guggenheim Museum in Bilbao has converted that Span- 
ish city, which hitherto went largely unnoticed on the international scene, into one of the five most visited cities in Spain. It is currently open to debate as to whether stadiums in general and the South African stadiums in particular fulfil the requirements for such positive external effects. ${ }^{21}$

\section{Summary}

The central theme of this paper is the claim that the economic impact of international tourist arrivals during a soccer World Cup such as the 2010 tournament in South Africa, is considerably smaller, at least in the short run, than is widely expected prior to the event. This phenomenon is not unique to South Africa, but the general result of most ex-post analyses of World Cups. The focus of this paper was on accurately estimating tourist arrivals during the World Cup because the immediate economic impact must derive from these arrivals. We found a modest number of arrivals - a net increase of tourists of some 40,000 to 90,000 persons compared to optimistic expectations, which would have constrained their impact on local income and employment. ${ }^{22}$ Self-defeating prophecies via an ex-ante supply-price-crowding-out channel have contributed to prevent international tourists to enter South Africa.

${ }^{21}$ For a general discussion of stadiums and urban development, see AHLFELDT \& MAENNIG (2010b). For the measurement of the external effects of stadiums, see TU (2005) and AHLFELDT \& MAENNIG (2009 and 2010a). For a discussion of the potential effects of South African stadiums, see DU PLESSIS \& MAENNIG (2009), MAENNIG \& DU PLESSIS (2009), and MAENNIG \& SCHWARTHOFF (in press).

22 DU PLESSIS \& VENTER (2010) calculated the likely impact on GDP of a comparably modest number of tourist arrivals. They found a short-run impact on net exports (after accounting for tourist expenditure in South Africa and South Africans' expenditure on tournament tickets) of $0.05 \%$ of GDP. Even assuming a multiplier of 2 for this component of net exports provides a modest estimate of $0.1 \%$ of GDP for the short-run impact of the tournament. 
At present, it is not possible to determine the likelihood of positive medium- or long-term effects of the 2010 World Cup; based upon empirical studies of comparable sporting events, it appears that such effects cannot be guaranteed. ${ }^{23}$

Though the "core" criteria of economic performance (such as income and employment) are usually the focus of impact studies, modern economics recognises other effects such as awareness and image effects as well. The paper indicated a rising awareness of South Africa that may well be one of the largest short-term economic effects of the tournament. There is widespread agreement that the 2010 World Cup was successfully hosted by friendly, relaxed and committed South Africans. The country takes pride in having passed such an important test under the scrutiny of the world (SCHIFFERLE, 2010). The positive media coverage and visual documentation of an incident-free World Cup has given South Africa a chance to reintroduce itself to the rest of the world. The depressing stories about crime, racial tension, HIV and power shortages have been displaced by a host of positive new images. This could translate into increased tourism and increased trade and attract foreign direct investors.

A channel by which the tournament could raise the long-run growth of the South African economy is through the impact on local self-confidence. The new selfconfidence is manifested in sporting affairs, as the revived ideas to organize Olympic Games may indicate. Beyond this, a poll conducted among 400 South Africans shows that $85 \%$ of South Africans now have more hope for a positive future for all South Africans than they did before the tournament (RASMUSSEN 2010). While the authors have little doubt on the potential for long-run positive economic effects, it is too early to find supporting statistical evidence. If this ex-

${ }^{23}$ For the 1974 soccer World Cup, no significant short-, medium- or long-term effects on employment in the German host cities can be seen (HAGN \& MAENNIG 2007a). For the 1996 Olympic Games in Atlanta, there are significant positive medium-term effects on employment, but no significant effects on wages (HOTCHKISS, MOORE \& ZOBEY 2003). With regard to the 1972 Olympic Games in Munich, there are significant positive long-term effects on incomes in the areas of Germany in which the contests took place, but no significant effect on employment (JASMAND \& MAENNIG 2007). For an overview of empirical studies on short-term effects and/or other sporting events, see DU PLESSIS \& MAENNIG (2007). 
pectation also proves to be overly optimistic, the South African Minister of Sport, MANKENKHESI STOFILE'S (2007) words may well prove accurate, that “The memory of that tournament will be a lasting legacy". 
HEED 37 - The 2010 World Cup High-frequency Data Economics

23

Appendix

Figure A1 Average Room Rates - Current Rand on a Daily Basis for June 2010

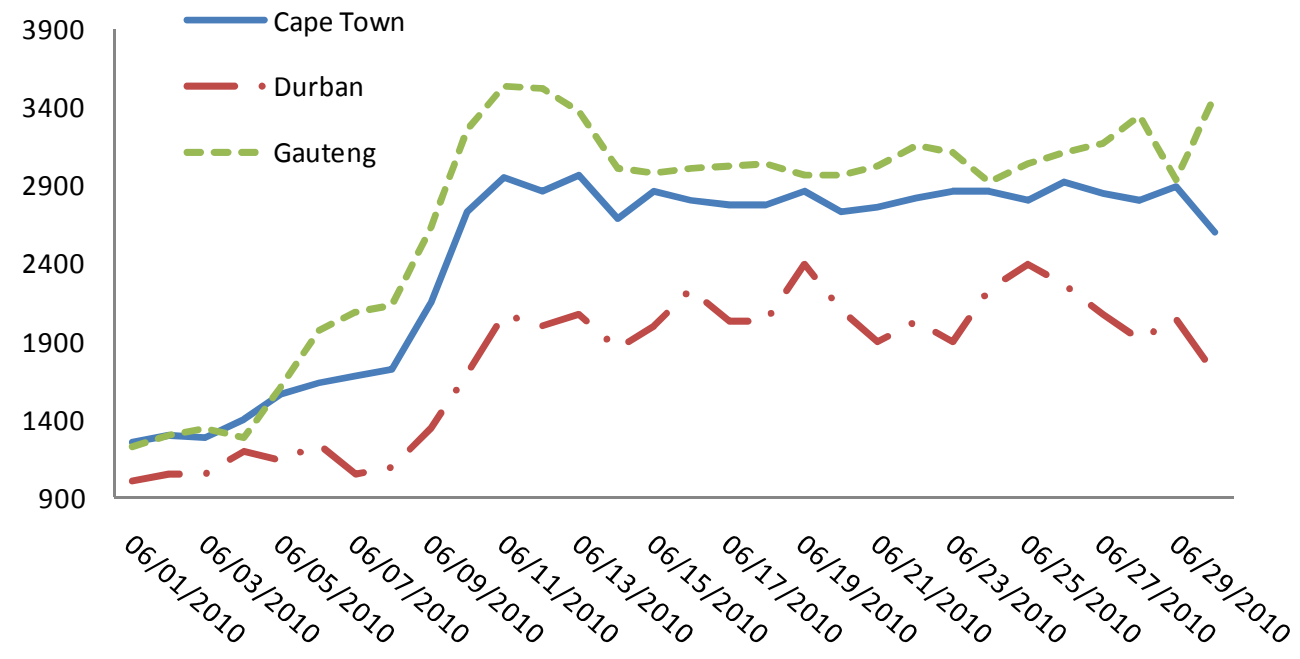




\section{Literature}

AHLFELDT, G. / MAENNIG, W. (2009), Arenas, Arena Architecture and the Impact on Location Desirability: The Case of 'Olympic Arenas' in Prenzlauer Berg, Berlin, in: Urban Studies, 46 (7), 1343-1362.

AHLFELDT, G. / MAENNIG, W. (2010a). Impact of Sports Arenas on Land Values: Evidence from Berlin, in: The Annals of Regional Science, 44 (2), 205-227.

AHLFELDT, G. / MAENNIG, W. (2010b), Stadium architecture and urban development from the perspective of urban economics, in International Journal of Urban and Regional Research, DOI:10.1111/j.1468-2427.2010.00908.x

ALLMERS, S / MAENNIG, W. (2009), Economic impacts of the FIFA Soccer World Cups in France 1998, Germany 2006, and outlook for South Africa 2010, in: Eastern Economic Journal, 35, 500-519

ATKINSON, G. / MOURATO, S / SZYMANSKI, S (2006), Quantifying the "un-quantifiable": Valuing the intangible Impacts of Hosting the Summer Olympic Games. London, unpublished manuscript, London School of Economics and Imperial College London.

BAADE, R.A. / MATHESON, V.A. (2004), The Quest for the Cup: Assessing the Economic Impact of the World Cup, Regional Studies 38 (4), 343-354.

BAUMANN, J. (2010). Fewer World Cup Visitors Than Expected, Business Day, 23 June 2010: 4

COATES, D. / HUMPHREYS, B.R. (2000), The stadium gambit and local economic development, Regulation: The Cato Review of Business and Government, 23(2), 15-20.

COKAYNE, R. (2010). Hotels May Go Bust as Room Rates Fall - Analyst, The Star, (18 June, 2010): 4

DEPARTMENT OF TOURISM (2010). Quick Facts: Government Preparations. 2010 FIFA World Cup South Africa. Pretoria. Department of Tourism, South African Government.

DU PLESSIS, S.A., / VENTER, C. (2010). The home team scores! A first assessment of the economic impact of World Cup 2010. Paper presented at the 10th International Hamburg Symposium "Sport and Economics" held in Hamburg on the 16th and 17th of July 2010.

DU PLESSIS, S.A. / MAENNIG, W. (2007), World Cup 2010, South African economic perspectives and policy challenges informed by the experience of Germany 2006, in: Contemporary Economic Policy, 25, 4, 578-590.

DU PLESSIS, S.A. / MAENNIG, W. (2009), South Africa 2010: Initial dreams and sobering economic perspectives, in: U. Pillay, R. Tomlinson, O. Bass (eds.), Development and dreams. The urban legacy of the football World Cup. Cape Town, 55-75.

GRANT THORNTON (2004). "2010 Soccer World Cup facts you should know." Retrieved 22 July 2006, from http://www.gauteng.net/research/pdf/soccer1.pdf.

GRANT THORNTON (2008), The Economic Impact of the 2010 Soccer World Cup.

FEDDERSEN, A. / MAENNIG, W. / BORCHERDING, M. (2006), New Stadia for the World Cup 2006 in Germany: Is the Novelty Effect Big Enough?, in: International Journal of Sport Finance, 1 (3), 174-188.

HAGN, F. / MAENNIG, W. (2007), Large sport events and unemployment: the case of the 2006 soccer World Cup in Germany, in: Applied Economics, 41, 3295-3302. 
HEYNE, M. / MAENNIG, W. / SÜSSMUTH, B. (2010), Induced Civic Pride and Integration, in: Oxford Bulletin of Economics and Statistics, 72(2), 202-220

HOTCHKISS, J. / MOORE, R. E. / ZOBEY, S. M. (2003), Impact of the 1996 Summer Olympic Games on Employment and Wages in Georgia, in: Southern Economic Journal, 69, 691-704.

JASMAND, ST. / MAENNIG, W. (2007), Regional Income and Employment Effects of the 1972 Munich Olympic Summer Games, in: Regional Studies, 42 (7), 991-1002.

JOHNSON, B.K. / WHITEHEAD, J.C. (2000), Value of public goods from sports stadiums: The CVM approach, Contemporary Economic Policy, 18 (1), 48-58.

MAENNIG, W. / DU PLESSIS, S. A. (2009), Sport Stadia, Sporting Events and Urban Development: International Experience and the Ambitions of Durban, in: Urban Forum, 20 (1), 61-76

MAENNIG, W. / SCHWARTHOFF, F. (in press), Stadiums and regional economic development: International experience and the plans of Durban, South Africa, in: Journal of Architectural and Planing Research Matheson, V.A. (2009), Economic multipliers and mega-event analysis, in: International Journal of Sport Finance, 4, 107-123

NAIDU, B. / PILISO, S. World Cup's R6.5bn Bonanza, The Sunday Times (20 June, 2010): 1

NELSON, A.C.: (2001), Prosperity or blight? A question of Major League Stadia Location, in: Economic Development Quarterly, 15, 255-265

NELSON, A.C. (2002), Locating Major league stadiums where they can make a difference: Empirical analysis with implications for all major public venues, in: Public works management policy, 7, 98-114.

N.N. (2010a), 2010 World Cup expected to bring in US 3.4 billion in revenue, http://www.eufootball.biz/finance/7151-2010_world_cup_expected_revenue.html 12.7.10

N.N. (2010 b), "It was a very attractive World Cup", sport intern, Vol. 42, iss. 20100711.

N.N. (2010 c). The Numbers don't Add Up, Business Day, 23 June 2010: 1

N.N. (2010 d), International criticism of world cup cost. http://yourworldcup2010.com/news/international-criticism-of-worldcuptravelcost.html 12.7.10.

PAM GOLDING (2010), Newsletter, June 2010.

PEDRONCELLI, P. (2010), The LOC is pleased with preparations for the World Cup, http://www.goal.com/en/news/1863/world-cup-2010/2010/04/09/1870139/worldcup-2010-organising-committee-set-to-deliver-world-cup , 12.7.10

RASMUSSEN, K. (2010), World Cup afterthoughts. Play the game, http://www.playthegame.org/news/detailed/world-cup-afterthoughts-4888.html, 18.7.10.

REEVES, N. (2010), Champions Spain back home, Blatter praises S.Africa, AFP press release,

http://www.google.com/hostednews/afp/article/ALeqM5ix7H7cwLP1132IXvWdcY_s iS5CPQ, from july 14 th, 2010

SAPA-AP, (2010). Hunting Industry Maimed by Pricey Tourism Event, The Star, 23 June 2010: 17 
SANTO, C. (2005), The economic impact of sports stadiums: Recasting the analysis in context, in: Journal of Urban Affairs, 27 (2), 177-192

SCHIFFERLE, T. (2010), Spain - Champion of an ambivalent World Cup, in TAGESANZEIGER, cited in: sport intern, Vol. 42, iss. 20100712

STATISTICS SOUTH AFRICA (2010), Tourism and Migraition, April 2010, downloaded from http://www.statssa.gov.za/publications/statsdownload.asp?ppn=P0351\&SCH=4681, 25 july 2010

TOLSI, N., (2010). Field of shattered dreams, Mail and Guardian, 13 May 2010: 10.

ZORN, R. (2010), Von Erleichterung bis Höhenrausch, in: Frankfurter Allgemeine. July 12th., 24. 


\section{Hamburg Contemporary Economic Discussions}

(Download: http://www.uni-hamburg.de/economicpolicy/discussions.html)

01/2005 FEDDERSEN, A. / MAENNIG, W.: Trends in Competitive Balance: Is there Evidence for Growing Imbalance in Professional Sport Leagues?, January 2005.

02/2005 SIEVERS, T.: Information-driven Clustering - An Alternative to the Knowledge Spillover Story, February 2005.

03/2005 SIEVERS, T.: A Vector-based Approach to Modeling Knowledge in Economics, February 2005.

04/2005 BUETTNER, N. / MAENNIG, W. / MENSSEN, M.: Zur Ableitung einfacher Multiplikatoren für die Planung von Infrastrukturkosten anhand der Aufwendungen für Sportstätten - eine Untersuchung anhand der Fußball-WM 2006, May 2005.

01/2006 FEDDERSEN, A.: Economic Consequences of the UEFA Champions League for National Championships - The Case of Germany, May 2006.

02/2006 FEDDERSEN, A.: Measuring Between-season Competitive Balance with Markov Chains, July 2006.

03/2006 FEDDERSEN, A. / VÖPEL, H.: Staatliche Hilfen für Profifußballclubs in finanziellen Notlagen? - Die Kommunen im Konflikt zwischen Imageeffekten und Moral-Hazard-Problemen, September 2006.

04/2006 MAENNIG, W. / SCHWARTHOFF, F.: Stadium Architecture and Regional Economic Development: International Experience and the Plans of Durban, October 2006. 


\section{Hamburg Contemporary Economic Discussions}

(Download: http://www.uni-hamburg.de/economicpolicy/discussions.html)

01

$\mathrm{O} 2$

03

04

05

06

07

08

09

10

11

12

13

AHLFELDT, G. / MAENNIG, W.: The Role of Architecture on Urban Revitalization: The Case of "Olympic Arenas" in Berlin-Prenzlauer Berg, 2007.

FEDDERSEN, A. / MAENNIG, W. / ZIMMERMANN, P.: How to Win the Olympic Games - The Empirics of Key Success Factors of Olympic Bids, 2007.

AHLFELDT, G. / MAENNIG, W.: The Impact of Sports Arenas on Land Values: Evidence from Berlin, 2007.

DU PLESSIS, S. I MAENNIG, W.: World Cup 2010: South African Economic Perspectives and Policy Challenges Informed by the Experience of Germany 2006, 2007.

HEYNE, M. / MAENNIG, W. / SUESSMUTH, B.: Mega-sporting Events as Experience Goods, 2007.

DUST, L. / MAENNIG, W.: Shrinking and Growing Metropolitan Areas-Asymmetric Real Estate Price Reactions? The Case of German Single-family Houses, 2007.

JASMAND, S. I MAENNIG, W.: Regional Income and Employment Effects of the 1972 Munich Olympic Summer Games, 2007.

HAGN, F. I MAENNIG W.: Labour Market Effects of the 2006 Soccer World Cup in Germany, 2007.

HAGN, F. / MAENNIG, W.: Employment Effects of the World Cup 1974 in Germany.

MAENNIG, W.: One Year Later: A Re-appraisal of the Economics of the 2006 Soccer World Cup, 2007.

AHLFELDT, G., MAENNIG, W.: Assessing External Effects of City Airports: Land Values in Berlin, 2007.

AHLFELDT, G.: If Alonso was Right: Accessibility as Determinant for Attractiveness of Urban Location, 2007.

AHLFELDT, G.: A New Central Station for a Unified City: Predicting Impact on Property Prices for Urban Railway Network Extension, 2007. 


\section{Hamburg Contemporary Economic Discussions}

(Download: http://www.uni-hamburg.de/economicpolicy/discussions.html)

14

15

16

17

18

19

20

21

22

FEDDERSEN, A. / MAENNIG, W.: Arenas vs. Multifunctional Stadia Which Do Spectators Prefer?, 2007.

AHLFELDT, G. / FEDDERSEN, A.: Geography of a Sports Metropolis, 2007.

FEDDERSEN, A. / GRÖTZINGER, A. / MAENNIG, W.: New Stadia and Regional Economic Development - Evidence from FIFA World Cup 2006 Stadia, 2008.

AHLFELDT, G. / MAENNIG, W.: Monumental Protection: Internal and External Price Effects, 2008.

MAENNIG, W. / PORSCHE, M.: The Feel-good Effect at Mega Sport Events - Recommendations for Public and Private Administration Informed by the Experience of the FIFA World Cup 2006, 2008.

AHLFELDT, G.: The Train has Left the Station: Real Estate Price Effects of Mainline Realignment in Berlin, 2008.

MAENNIG, W. / WELLBROCK, C.-M.: Sozio-ökonomische Schätzungen Olympischer Medaillengewinne: Analyse-, Prognose- und Benchmarkmöglichkeiten, 2008.

MAENNIG, W. / ALLERMS, S.: South Africa 2010: Economic Scope and Limits, 2008.

AHLFELDT, G. / FEDDERSEN, A.: Determinants of Spatial Weights in Spatial Wage Equations: A Sensitivity Analysis, 2008.

AHLFELDT, G. / WENDLAND, N.: Fifty Years of Urban Accessibility: The Impact of Urban Railway Network on the Land Gradient in Industrializing Berlin, 2008.

AHLFELDT, G. / FRANKE, B. / MAENNIG, W.: Terrorism and the Regional and Religious Risk Perception of Foreigners: The Case of German Tourists, 2009.

FEDDERSEN, A. / MAENNIG, W.: Wage and Employment Effects of the Olympic Games in Atlanta 1996 Reconsidered, 2009.

AHLFELDT, G. I MAENNIG, W.: Impact of Non-Smoking Ordinances on Hospitality Revenues: The Case of Germany, 2009. 


\section{Hamburg Contemporary Economic Discussions}

(Download: http://www.uni-hamburg.de/economicpolicy/discussions.html)

BJØRNSKOV , C. / DREHER, A. / FISCHER, J.A.V. / SCHNELLENBACH, J.: On the Relation Between Income Inequality and Happiness: Do Fairness Perceptions Matter?, 2009.

AHLFELDT, G. / MAENNIG, W. / OSTERHEIDER, T.: Regional and sectoral effects of a common monetary policy: evidence from Euro Referenda in Denmark and Sweden, 2009.

FEDDERSEN, A. / JACOBSEN, S. / MAENNIG, W.: Sports Heroes and Mass Sports Participation - The (Double) Paradox of the "German Tennis Boom", 2009.

AHLFELDT, G. / MAENNIG, W. / ÖLSCHLÄGER, M.: Lifestyles and Preferences for (Public) Goods: Professional Football in Munich, 2009.

FALCH, T. / FISCHER, J.A.V.: Public Sector Decentralization and School Performance: International Evidence, 2010.

AHLFELDT, G.: Blessing or curse? Appreciation, Amenities, and Resistance around the Berlin "Mediaspree", 2010.

FEDDERSEN, A. / MAENNIG, W.: Sectoral Labor Market Effects of the 2006 FIFA World Cup, 2010.

FISCHER, J.A.V. / SOUSA-POZA, A.: The Impact of Institutions on Firms Rejuvenation Policies: Early Retirement with Severance Pay versus Simple Lay-Off. A Cross-European Analysis, 2010.

FEDDERSEN, A. / MAENNIG, W.: Mega-Events and Sectoral Employment: The Case of the 1996 Olympic Games, 2010.

BISCHOFF, O.: Explaining Regional Variation in Equilibrium Real Estate Prices and Income, 2010.

DU PLESSIS, S. A. / MAENNIG, W.: The 2010 World Cup Highfrequency Data Economics: Effects on International Awareness and (Self-defeating) Tourism, 2010 


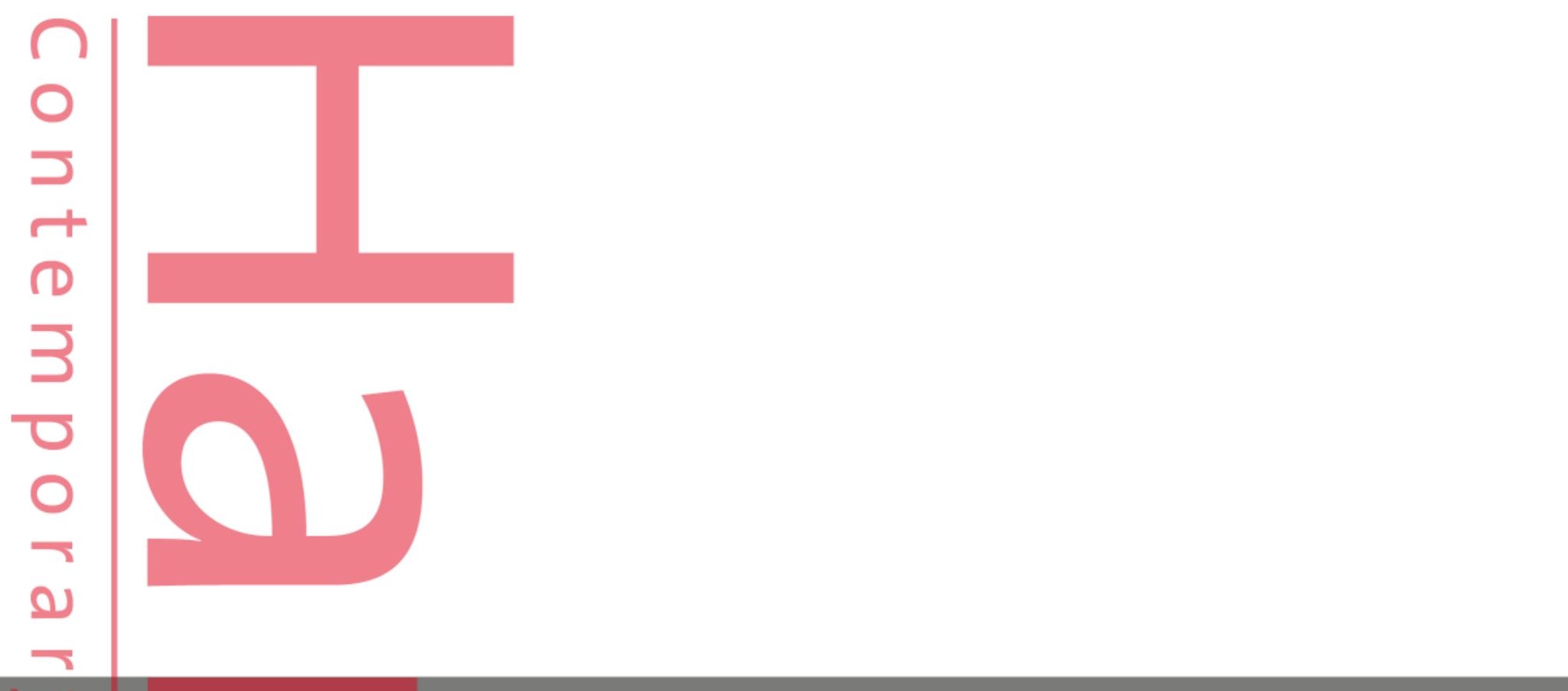

ISSN 1865-2441 (PRINT) ISSN $1865-7133$ (ONLINE)

ISBN 978-3-940369-88-8 (PRINT) ISBN 978-3-940369-89-5 (ONLINE) 